\title{
Assessment of Ferroresonance Processes in Schemes of 6-35 kV Electrical Grids on the Basis of Reliability Analysis
}

\author{
Zinovii Bakhor, Andrii Yatseiko, Roman Ferensovych ${ }^{*}$ \\ Lviv Polytechnic National University, 12 Stepana Bandery St., Lviv, 79013, Ukraine
}

Received: October 01, 2020. Revised: November 06, 2020. Accepted: November 13, 2020.

(c) 2020 The Authors. Published by Lviv Polytechnic National University.

\begin{abstract}
The object of research is the choice of the optimal technical solution to prevent the development or the long existence of ferroresonance processes in electrical distribution grids of $6-35 \mathrm{kV}$, which are operated in isolated neutral mode. A lot of factors such as the grounding mode of a grid neutral, its capacitive current of a short circuit to the ground, the type and number of voltage transformers (VT) etc. influence on the probability of occurrence and duration of ferroresonance processes. According to the results of the research, the values of capacitive currents of a short circuit to the ground at which stable ferroresonance processes occur in electrical distribution grids of 6-35 kV are determined. The values of capacitive earth fault currents of a grid are decisive for the occurrence of a stable ferroresonance, but the nature of its flow is also influenced by additional accidental factors, such as: a grid voltage, an insulation status of power lines, a load of the secondary winding of voltage transformer etc. Therefore, a model for assessment the frequency of occurrence of a stable ferroresonance process in the electrical grid based on the analysis of the reliability of physical objects in the conditions of external actions was developed. In addition, an algorithm for determining the most dangerous scheme configurations of electrical grids concerning to a VT damage by the frequency of occurrence of a stable ferroresonance process in them and the choice of optimal solutions to prevent the VT damage were proposed.
\end{abstract}

Keywords: electrical grid; ferroresonance; voltage transformer; isolated neutral; reliability analysis.

\section{Introduction}

In the electrical grids of 6-35 $\mathrm{kV}$ with isolated neutral, the stable and unstable ferroresonance processes (FRP) can occur during certain processes associated with the appearance of internal overvoltages in the network (switching overvoltages, phase-to-earth faults). A lot of factors such as the grounding mode of grid neutral, network parameters its capacitive earth fault current, an availability of voltage transformers (VT), their type and number, the schemes of winding connection, features of the magnetic system, the parameters of VT and a characteristic of their magnetization curves etc. - influence on the probability of occurrence and duration of ferroresonance processes. The stable FRP most often occur in grids with isolated neutral and are dangerous for VT, as they cause to thermal damage of their primary windings.

Factors such as the accidental occurrence of FRP in the electrical grids, the operation of a significant number of VT in the electrical distribution grids (EDG), which due to their design allow the occurrence of a stable FRP, the VT damage, indicate the importance of preventing the occurrence and a long existence of FRP in such electrical grids. This task consists in the selection and acceptance an effective decision both at the design stage of the development of electrical distribution grids and during their operation. Currently, the means and measures are developed to prevent

* Corresponding author. Email address: femary@ukr.net

This paper should be cited as: Z. Bakhor, A. Yatseiko, R. Ferensovych. Assessment of ferroresonance processes in schemes of 6-35 kV electrical grids on the basis of reliability analysis. Energy Engineering and Control Systems, 2020, Vol. 6, No. 2, pp. 137 - 145. https://doi.org/10.23939/jeecs2020.02.137 
the stable FRP in the distribution grids. In addition, the antiresonant VT [1]-[9] are designed and the regulations papers [10] regulate their assembling on the new electrical substations.

For different types of VT in the EDG the choice of the optimal solution (measure, means) is influenced by its cost, the scheme of an electrical grid, a design and a length of its power lines, the configuration of a network under the condition of a stable FRP. Therefore, the development of a decision-making algorithm to prevent a stable FRP in the EDG, taking into account the known means and measures both at the design stage of the electrical grid development and during the operation of existing electrical grids, is relevant and topical.

\section{The research object}

The ferroresonance processes in the electrical distribution grids of $6-35 \mathrm{kV}$ are the object of research in the paper.

\section{Research aim and objectives}

The purpose of research is to develop an algorithm for the choice of the optimal technical measure to prevent a stable FRP in the EDG, which will allow formalizing the procedure for selecting a measure with providing the efficient use of funds to improve a quality of the grid operation in both cases: at the design stage of EDG development and during their operation.

To achieve this purpose it is necessary to solve the following tasks:

- according to the results of the investigation of FRP in the EDG of 6-35 kV it is necessary to determine the values of capacitive earth fault currents at which in the grid for the different types of VT the stable FRP occur;

- it is necessary to develop a model for an assessment the frequency of the occurrence of a stable FRP in the network based on the analysis of the reliability of physical objects in the conditions of external actions;

- it is necessary to develop an algorithm for selecting the optimal technical measure to prevent a stable FRP in the EDG taking into account the implementation cost of the measure.

\section{Analysis of the recent studies and publications}

Many articles [1]-[9], [13]-[17] describe the FRP in the EDG of 6-35 kV, which operate with isolated neutral.

The causes of damage of the VT during the FRP, the analysis of the factors that lead to their occurrence, the flow nature and the means of elimination of emergencies in the electrical grids are described in the papers [3], [4]. However, there are some aspects of the problem of occurrence of FRP and damage of the VT during their flow in power grids, which were obtained during a research and presented in articles [1]-[8], [13]-[15].

The ferroresonances in the network occur if the values of capacitive earth fault currents are from $0.3 \mathrm{~A}$ to $3.5 \mathrm{~A}$ per one VT. We also clarify that in the technical literature, including the author's articles, a capacitive current to ground $1 \div 2 \mathrm{~A}$ was one of the conditions for the occurrence of the ferroresonance. This is so-called "perfect range" of capacitive currents, at which the ferroresonance will occur under any other conditions [3].

The occurrence of ferroresonance in the grid depends on the voltage levels of substations where the VT are mounted. The higher voltage causes the greater probability of occurrence of the FRP [1].

The appearance of ferroresonance significantly depends on the weather conditions (it will not occur: in winter during a snowfall, the presence of a hoarfrost, a frost; at the other times of the year - during the rains, heavy rains, a high humidity etc.). The presence of the active component of the earth fault current with the amount $\geq 1 \%$ of the capacitive component not allows the development of a stable ferroresonance [6].

The VT of NTMI (HTMИ) and ZNOM (3HOM) types and similar in design must be operated with the resistor with the parameters: $R=25 \mathrm{Ohms} ; P=400 \mathrm{~W}$, which is constantly switched on in the winding of "an open triangle". If the resistor is absent, then during various switchings in the electrical grid (including the appearance and break of the connection to the ground), dangerous oscillating processes can occur in the power grids with the frequencies of $50,100,150 \ldots \mathrm{Hz}[6]$.

The appearance of ferroresonance does not depend on the moment of a break of the capacitive earth fault current [1]. 
The appearance of ferroresonance depends on the magnetization characteristics of the VT. Repaired transformers resonate more often than new ones because their magnetization characteristics become gentler [7]-[9], [14].

The ferroresonance to a small extent depends on the load of the VT, especially at the limit values of $I_{c}$ and $U_{\text {rated }}$. The greater load of the VT causes the less probability of the appearance of FRP [1].

To prevent the VT damage from the FRP the various measures are offered in the literature:

- the most radical it is changing the operation mode of the neutral in the power grids (their operation with resonant, resistive, combined or even effective neutral grounding);

- use of various antiresonant (non-resonant) VT [1], [4], [10] or use of specialized systems for continuous monitoring of power grids and prevention of the occurrence or failure of the ferroresonance [1], [4], [17].

It is clear that the radical method requires huge costs and the concept change of the construction of such electrical grids. In addition, the use of so-called antiresonant VT is not as effective as the developers of these transformers describe. This is shown by us (and other authors), for example, in articles [1], [4]. The only non-resonant VT of NTN (HTH) type [11] is not damaged by the FRP in the electrical grids of 6-35 kV because such processes cannot occur in the networks with such VT.

The devices SmartLoad and VT Guard, Haefely, PZF (ПЗФ) [1] are used in electrical grids to prevent the occurrence or failure of the ferroresonance. Also for this purpose the antiresonant VT of NAMI (HAMИ), NAMIT (НАМИТ) types, non-resonant VT of NTN type [1], [11] are operated in power grids. In addition, the protection devices of PZF type are successfully operated in the electrical grids of $6-35 \mathrm{kV}$ for more than 20 years and are installed on VT of NTMI, ZNOM types (and similar in design VT) that operate in the networks.

\section{Presentation of the main material}

The FRP can occur in the electrical grids of 6-35 kV that operate with isolated neutral and have a significant number of different types of electromagnetic VT. The research [1]-[6] has shown that there are possible three cases for the VT or a VT group, depending on the network mode, its parameters and type of VT: the FRP does not occur in the grid; an unstable FRP occurs; a stable FRP occurs.

The occurrence of FRP in the electrical grids and a steady course of FRP at the definite capacitive currents in the network are typical both for VT of NTMI, ZNOM types and for the new antiresonant VT (for example, NAMI type). A stable FRP in the network causes the damage of the VT.

Therefore, the various means and measures are developed, the actions of which are aimed at preventing the existence of a stable FRP in the power grid (for example, application of devices of PZF type (Fig.1)). Such measures also allow preventing the development of emergencies.

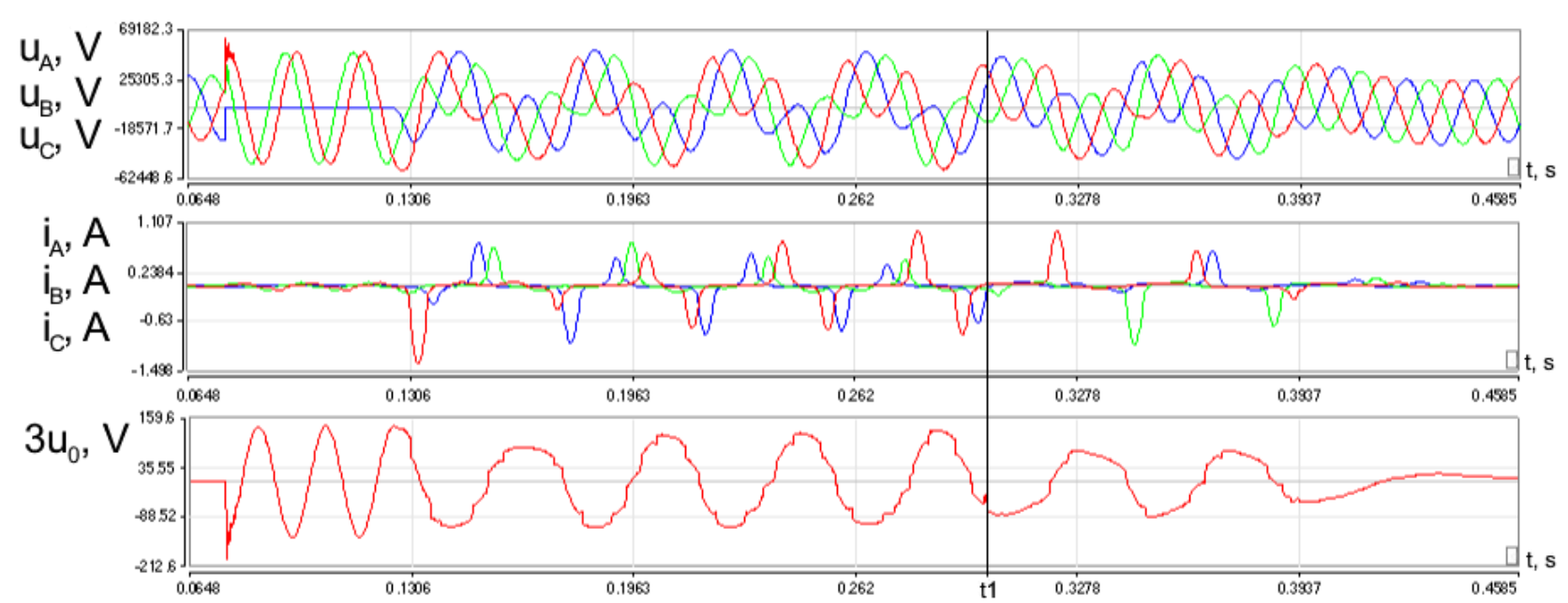

Fig.1. The nature of the development of ferroresonance process during operation of the device of PZF type at time moment $t$. 
During the design of the new substations for electrical distribution grids of $6-35 \mathrm{kV}$ with an isolated neutral (unloading centers), a performance of the projects of electrical grid development, a reconstruction of existing power transmission lines and substations, it is necessary to take into account that under certain conditions (the network configuration, the type and number of VT) the FRP can occur in the power grid. It is also necessary to take into account during the performance of works to improve the operation efficiency of the grids by the assembling protection systems against FRP on the VT or their replacement by the antiresonant VT. Therefore, both during the design works of the development and reconstruction of the EDG and during their operation, it is advisable to assess the possibility of occurrence of a stable FRP in the power grid. Then it is necessary to determine for the scheme of EDG its dangerous configurations that may occur during the operation of the grid after the operational commutations.

We propose to classify each permissible configuration of the electrical grid in relation to the occurrence and development of FRP as a normal or dangerous class. The normal class will include the electrical grids (their configurations), a perturbation in which does not lead to the occurrence of FRP (FRP does not occur at all) or after perturbation in the grid the FRP occurs but subsides after a short time interval 0.02 seconds (Fig.2). The class of dangerous network configuration includes those networks in which after perturbation a stable FRP occurs, during which the VT will be damaged (Fig.3). The type of VT and the current $I_{\mathrm{c} 0}$ are the classification features of electrical grid.

During the design of new substations according to the regulation papers [10], it is necessary to install the antiresonant VT. There are two groups of VT: the VT with a capacitive divider and electromagnetic VT with a special design - the antiresonant VT. The use a VT with a capacitive divider of NTN type in the electrical grid does not lead to the occurrence of FRP (Fig.2).

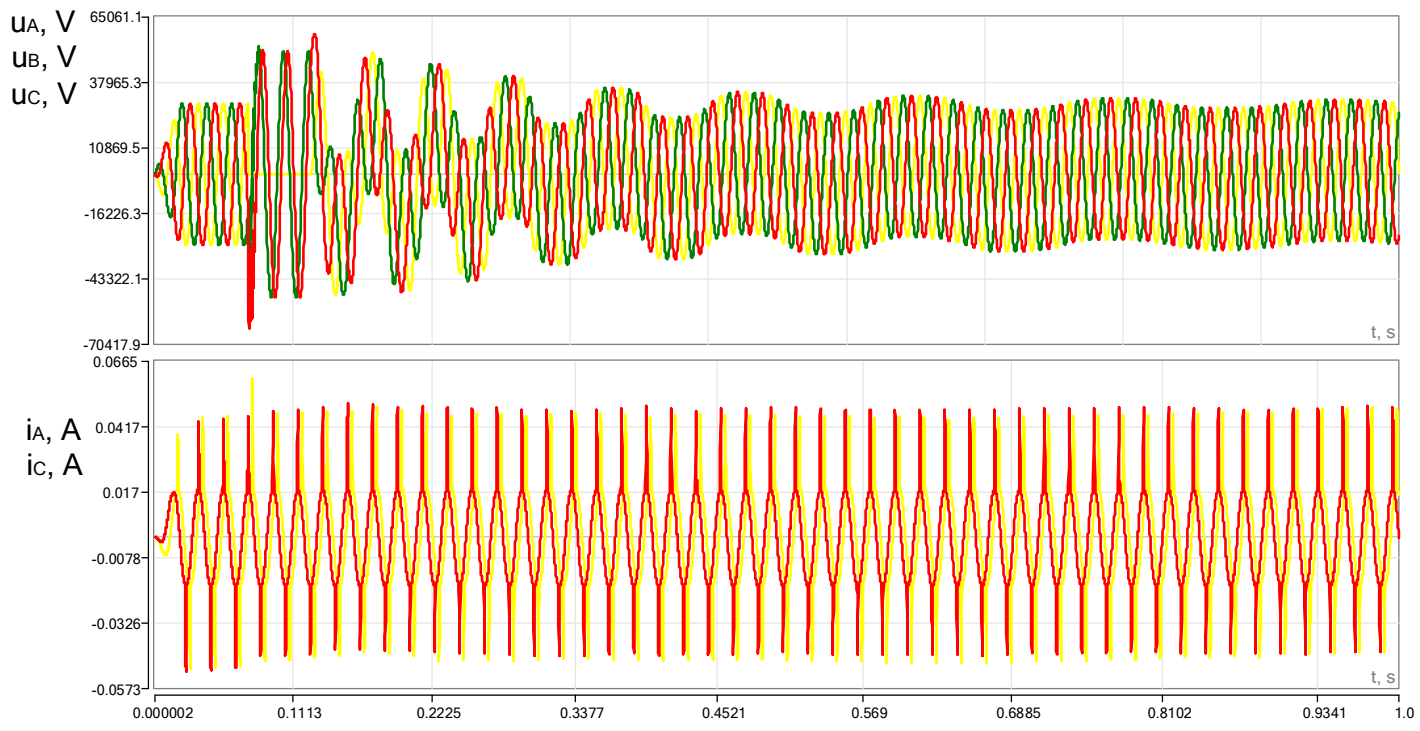

Fig.2. The nature of the development of ferroresonance process in the electrical grid with VT of NTN type.

Another mode is observed with antiresonant VT of NAMIT type, when under certain conditions in the electrical grid a FRP occurs. Due to the construction of VT, it can quickly subside or go into a stable oscillating process. The use of antiresonant electromagnetic VT of NAMI type creates the risks of occurrence of stable FRP in the networks (Fig.3), as is shown in [1]-[3], [5]. Therefore, it is necessary to use the VT of NTN type on the new substations because then in the electrical grids of $6-35 \mathrm{kV}$, which are powered by substation busbars, the stable FRP will not occur. The use of VT of NAMI or NAMIT type requires an assessment of the possibility that the stable FRP will occur. 


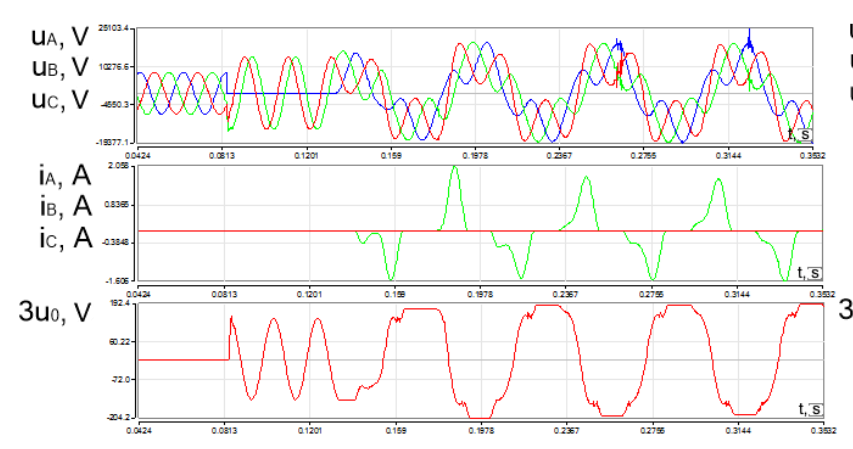

$a$

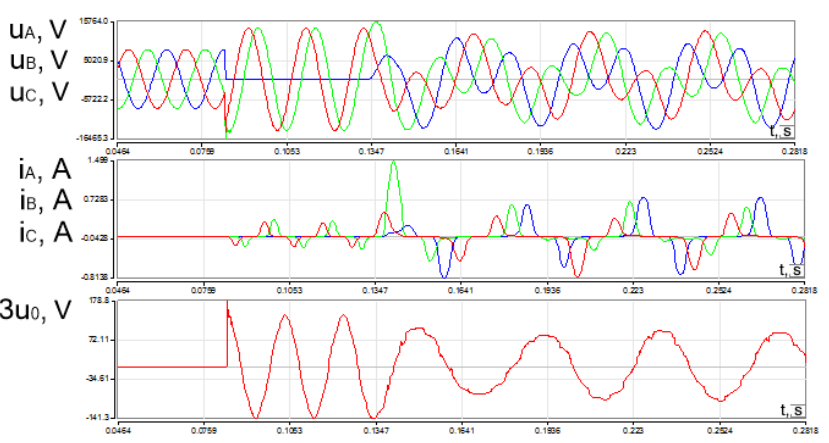

$b$

Fig.3. The nature of the development of ferroresonance process during the application of the VT of NAMI $(a)$ and NAMIT type (b).

In other design tasks (a development of electrical distribution grid; a reconstruction of power transmission lines; a reconstruction of substations that supply a power to the electrical distribution grids), the analysis of possible states (configurations) of the electrical grid is necessary in order to assess the possibility of occurrence of a stable FRP. The same applies to all VT of NTMI, ZNOM, NAMI types, which are operated in the electrical distribution grids of 6$35 \mathrm{kV}$.

In the case if the possibility of a stable FRP in the electrical grid with the VT exists, the question of a choice of the optimal method of preventing such process is important. It can be the installation of protection system against FRP on the working VT or the replacement of the working VT with a new antiresonant VT when there is no dangerous state of the electrical grid.

The ranges of capacitive earth fault currents from $I_{\mathrm{c} 0 \min }$ to $I_{\mathrm{c} 0 \max }$ are determined in the Tables 1 and 2 for the main types of VT, at which the stable FRP occurs.

Table 1. The ranges of capacitive earth fault currents from $I_{\mathrm{c} 0 \min }$ to $I_{\mathrm{c} 0 \max }$ at which there are the stable FRP at a frequency of $50 \mathrm{~Hz}$.

\begin{tabular}{|c|c|c|c|c|c|c|c|c|}
\hline \multirow{2}{*}{$\frac{\stackrel{0}{2}}{5}$} & \multirow{2}{*}{\multicolumn{2}{|c|}{ Number of VT }} & \multicolumn{2}{|c|}{$0,9 \mathrm{U}$} & \multicolumn{2}{|c|}{$\mathbf{U}$} & \multicolumn{2}{|c|}{$1,15 U$} \\
\hline & & & from & to & from & to & from & to \\
\hline \multirow{6}{*}{$\sum_{\mathbf{Z}}^{\stackrel{\varphi}{\mid}}$} & \multirow{2}{*}{1} & Ic, A & 0.1 & 0.2 & 0.1 & 0.3 & 0.1 & 0.4 \\
\hline & & $\mathrm{C}, \mu \mathrm{F}$ & 0.0306 & 0.0612 & 0.0306 & 0.0918 & 0.0306 & 0.1224 \\
\hline & \multirow{2}{*}{2} & $\mathrm{Ic}, \mathrm{A}$ & 0.2 & 0.4 & 0.2 & 0.6 & 0.2 & 0.8 \\
\hline & & $\mathrm{C}, \mu \mathrm{F}$ & 0.0612 & 0.1224 & 0.0612 & 0.1836 & 0.0612 & 0.8 \\
\hline & \multirow{2}{*}{3} & Ic, $\mathrm{A}$ & 0.3 & 0.6 & 0.3 & 0.9 & 0.3 & 1.2 \\
\hline & & $\mathrm{C}, \mu \mathrm{F}$ & 0.0918 & 0.1836 & 0.0918 & 0.2754 & 0.0918 & 0.3672 \\
\hline \multirow{6}{*}{$\underset{\mathbf{z}}{\stackrel{ }{\operatorname{s}}}$} & \multirow{2}{*}{1} & Ic, $\mathrm{A}$ & 0.2 & 0.3 & 0.25 & 0.35 & 0.25 & 0.4 \\
\hline & & $\mathrm{C}, \mu \mathrm{F}$ & 0.0368 & 0.0552 & 0.0459 & 0.0644 & 0.0459 & 0.0736 \\
\hline & \multirow{2}{*}{2} & Ic, A & 0.2 & 0.6 & 0.25 & 0.7 & 0.25 & 0.8 \\
\hline & & $\mathrm{C}, \mu \mathrm{F}$ & 0.0368 & 0.1103 & 0.0459 & 0.129 & 0.0459 & 0.147 \\
\hline & \multirow{2}{*}{3} & Ic, $\mathrm{A}$ & 0.2 & 0.9 & 0.25 & 1.05 & 0.25 & 1.2 \\
\hline & & $\mathrm{C}, \mu \mathrm{F}$ & 0.0368 & 0.1655 & 0.0459 & 0.193 & 0.0459 & 0.221 \\
\hline \multirow{6}{*}{ 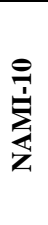 } & \multirow{2}{*}{1} & Ic, $\mathrm{A}$ & 0.1 & 0.2 & 0.1 & 0.25 & 0.1 & 0.25 \\
\hline & & $\mathrm{C}, \mu \mathrm{F}$ & 0.01839 & 0.0368 & 0.01839 & 0.0459 & 0.01839 & 0.0459 \\
\hline & \multirow{2}{*}{2} & Ic, $\mathrm{A}$ & 0.15 & 0.4 & 0.2 & 0.4 & 0.25 & 0.4 \\
\hline & & $\mathrm{C}, \mu \mathrm{F}$ & 0.0276 & 0.0736 & 0.0368 & 0.0736 & 0.0459 & 0.0736 \\
\hline & \multirow{2}{*}{3} & $\mathrm{Ic}, \mathrm{A}$ & 0.15 & 0.45 & 0.2 & 0.6 & 0.25 & 0.6 \\
\hline & & $\mathrm{C}, \mu \mathrm{F}$ & 0.0276 & 0.0828 & 0.0368 & 0.1103 & 0.0459 & 0.1103 \\
\hline
\end{tabular}


Table 2. The ranges of capacitive earth fault currents from $I_{\mathrm{c} 0 \min }$ to $I_{\mathrm{c} 0 \max }$ at which there are the stable FRP at subharmonic frequencies.

\begin{tabular}{|c|c|c|c|c|c|c|c|c|c|}
\hline \multirow{2}{*}{$\underset{3}{3}$} & \multicolumn{2}{|c|}{ Number of VT } & \multicolumn{2}{|c|}{$0,9 \mathrm{U}$} & \multicolumn{2}{|c|}{$\mathbf{U}$} & \multicolumn{2}{|c|}{$1,15 U$} & \multirow{3}{*}{$\begin{array}{c}\begin{array}{c}\text { Frequency } \\
\text { of FRP, } \\
\mathbf{H z}\end{array} \\
\\
25\end{array}$} \\
\hline & & & from & to & from & to & from & to & \\
\hline \multirow{6}{*}{$\sum_{i}^{\stackrel{\nu}{i}}$} & \multirow{2}{*}{1} & Ic, A & 0.25 & 1.9 & 0.35 & 2.2 & 0.5 & 2.4 & \\
\hline & & $\mathrm{C}, \mu \mathrm{F}$ & 0.0765 & 0.5814 & 0.1071 & 0.6732 & 0.153 & 0.7344 & 25 \\
\hline & \multirow{2}{*}{2} & Ic, $\mathrm{A}$ & 0.5 & 3.8 & 0.7 & 4.4 & 1 & 4.8 & 25 \\
\hline & & $\mathrm{C}, \mu \mathrm{F}$ & 0.153 & 1.163 & 0.214 & 1.346 & 0.306 & 1.469 & 25 \\
\hline & \multirow{2}{*}{3} & Ic, A & 0.75 & 5.7 & 1.05 & 6.6 & 1.5 & 7.2 & 25 \\
\hline & & $\mathrm{C}, \mu \mathrm{F}$ & 0.229 & 1.744 & 0.321 & 2.019 & 0.459 & 2.203 & 25 \\
\hline \multirow{6}{*}{ 竞 } & \multirow{2}{*}{1} & Ic, A & 0.35 & 2.3 & 0.5 & 2.55 & 0.45 & 2.85 & 25 \\
\hline & & $\mathrm{C}, \mu \mathrm{F}$ & 0.0644 & 0.423 & 0.0919 & 0.469 & 0.0828 & 0.524 & 25 \\
\hline & \multirow{2}{*}{2} & Ic, A & 0.7 & 4.6 & 1 & 5.1 & 0.9 & 5.7 & 25 \\
\hline & & $\mathrm{C}, \mu \mathrm{F}$ & 0.129 & 0.846 & 0.1839 & 0.938 & 0.166 & 1.048 & 25 \\
\hline & \multirow{2}{*}{3} & Ic, A & 1.05 & 6.9 & 1.5 & 7.65 & 1.35 & 8.55 & 25 \\
\hline & & $\mathrm{C}, \mu \mathrm{F}$ & 0.193 & 1.269 & 0.276 & 1.407 & 0.248 & 1.573 & 25 \\
\hline \multirow{6}{*}{$\underset{\sum}{\stackrel{ }{\mid}}$} & \multirow{2}{*}{1} & Ic, A & 0.15 & 1 & 0.25 & 1.15 & 0.25 & 1.45 & 17 \\
\hline & & $\mathrm{C}, \mu \mathrm{F}$ & 0.0276 & 0.1839 & 0.0459 & 0.211 & 0.0459 & 0.2667 & 17 \\
\hline & \multirow{2}{*}{2} & Ic, A & 0.3 & 2 & 0.5 & 2.3 & 0.5 & 2.9 & 17 \\
\hline & & $\mathrm{C}, \mu \mathrm{F}$ & 0.0552 & 0.368 & 0.0919 & 0.423 & 0.0919 & 0.533 & 17 \\
\hline & \multirow{2}{*}{3} & Ic, $\mathrm{A}$ & 0.45 & 3 & 0.75 & 3.45 & 0.75 & 4.35 & 17 \\
\hline & & $\mathrm{C}, \mu \mathrm{F}$ & 0.0828 & 0.5517 & 0.138 & 0.634 & 0.138 & 0.7999 & 17 \\
\hline \multirow{6}{*}{ 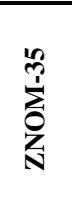 } & \multirow{2}{*}{1} & Ic, A & 0.45 & 1.75 & 0.55 & 2.1 & 0.5 & 2.35 & 25 \\
\hline & & $\mathrm{C}, \mu \mathrm{F}$ & 0.0236 & 0.0919 & 0.0289 & 0.1103 & 0.0263 & 0.1234 & 25 \\
\hline & \multirow{2}{*}{2} & Ic, A & 0.9 & 3.5 & 1.1 & 4.2 & 1 & 4.7 & 25 \\
\hline & & $\mathrm{C}, \mu \mathrm{F}$ & 0.0473 & 0.184 & 0.0578 & 0.221 & 0.05253 & 0.2469 & 25 \\
\hline & \multirow{2}{*}{3} & Ic, A & 1.35 & 5.25 & 1.65 & 6.3 & 1.5 & 7.05 & 25 \\
\hline & & $\mathrm{C}, \mu \mathrm{F}$ & 0.0709 & 0.276 & 0.0867 & 0.331 & 0.0788 & 0.3703 & 25 \\
\hline \multirow{6}{*}{ 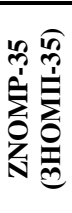 } & \multirow{2}{*}{1} & Ic, A & 0.45 & 2 & 0.55 & 2.4 & 0.5 & 2.7 & 25 \\
\hline & & $\mathrm{C}, \mu \mathrm{F}$ & 0.0236 & 0.105 & 0.0289 & 0.126 & 0.0263 & 0.1416 & 25 \\
\hline & \multirow{2}{*}{2} & Ic, A & 0.9 & 4 & 1.1 & 4.8 & 1 & 5.4 & 25 \\
\hline & & $\mathrm{C}, \mu \mathrm{F}$ & 0.0473 & 0.21 & 0.0578 & 0.252 & 0.05253 & 0.2832 & 25 \\
\hline & \multirow{2}{*}{3} & Ic, A & 1.35 & 6 & 1.65 & 7.2 & 1.5 & 8.1 & 25 \\
\hline & & $\mathrm{C}, \mu \mathrm{F}$ & 0.0709 & 0.315 & 0.0867 & 0.378 & 0.0788 & 0.4248 & 25 \\
\hline
\end{tabular}

During the analysis of the EDG scheme, we determine a finite set of realistically possible configurations of the network scheme $\left\{C N_{1}, C N_{2}, \ldots, C N_{\mathrm{k}}\right\}$. Each configuration of the electrical grid scheme from the set $\boldsymbol{C N}$ corresponds to the value of capacitive earth fault current. Thus, we will obtain a set of discrete values of capacitive earth fault currents $\left\{I_{\mathrm{c} 01}, I_{\mathrm{c} 02}, \ldots, I_{\mathrm{c} 0 \mathrm{k}}\right\}$, which correspond to the set of states of EDG scheme.

The next step is to create a set of dangerous configurations of the scheme of district electrical grid $\boldsymbol{D C N}$. Thus, if a current $I_{\mathrm{c} 0 \mathrm{i}}$ is in the range of capacitive earth fault currents for the VT, the $i$-th network configuration scheme $\left(C N_{\mathrm{i}} \in\right.$ $\boldsymbol{C N}$ ) will belong to the set $\boldsymbol{D C N}$, when the condition is

$$
C N_{\mathrm{i}} \in D C N \Leftrightarrow I_{\mathrm{c} 0 \mathrm{i}} \geq I_{\mathrm{c} 0 \min } \wedge I_{\mathrm{c} 0 \mathrm{i}} \leq I_{\mathrm{c} 0 \max }
$$

It should be noted that the capacitive currents of the electrical grid are decisive for the occurrence of a stable FRP. However, the nature of the FRP is also influenced by additional random factors such as a network voltage at the time of occurrence of FRP, a state of the insulation of network lines, the load of secondary winding of VT [1]. The values of these additional factors (the value of the voltage $U$, the active conductivity to the ground of power transmission lines $g$, the load resistance of the secondary winding of VT $R_{L}$ ) form a multidimensional vector of independent components $\vec{x}=\left(U, g, R_{L}\right)$.

The frequency of the occurrence of FRP for each $i$-th network configuration from the set $\boldsymbol{D C N}$ can be calculated by the equation

$$
\omega=n_{\text {spef }} \cdot q
$$


where $n_{\text {spef }}$ is the number of single-phase earth faults per year in the power transmission lines of the i-th network configuration; $q$ is the probability of occurrence of a ferroresonance process during a single earth fault.

For the calculation of the probability of FRP during a single-phase earth fault in the i-th network configuration we have used the methods of reliability analysis of physical objects in the conditions of external actions and the calculation algorithm from [12], which we have adapted to our task.

The calculation of the probability of FRP in the $i$-th network configuration during the one earth fault is performed using a model of the probability of object failure in the case of one external action [12], because the appearance of the stable FRP in the electrical grid leads to the damage of VT,

$$
q=\int \underset{D_{x}}{\int \ldots \int} f(\vec{x}) \prod_{k=1}^{n} d x_{k}
$$

where $x_{k}$ is a $k$-th component of the multidimensional vector $\vec{x} ; n$ is a number of components; $f(\vec{x})$ is a function of distribution density of the vector $\vec{x} ; D_{x}$ is an integral area (an area of dangerous parameters of the vector $\vec{x}$ ).

Taking into account the independent components of the vector $\vec{x}$, an equation (3) takes the form

$$
q=\int \ldots \int \prod_{D_{x}}^{3} f\left(x_{k}\right) d x_{k}=\int \ldots \int \prod_{D_{x}}^{3} d F\left(x_{k}\right)
$$

where $f\left(x_{k}\right)$ is a function of the distribution density of $k$-th component of the vector $\vec{x} ; d F\left(x_{k}\right)$ is a differential of the distribution function of $k$-th component of the vector $\vec{x}$.

From the equation (4) after the corresponding replacements and transformations, we will obtain the equation for calculation the probability of the occurrence of FRP during the one earth fault in $i$-th network configuration with the VT, which has the form

$$
q_{F R P i}=\sum_{U \in D_{f i}} \Delta F(U) \sum_{g \in D_{f i}} \Delta F(g) \sum_{R_{L} \in D_{f i}} \Delta F\left(R_{L}\right)
$$

where $D_{f i}$ is an area of dangerous parameters of the components of the vector $\vec{x}$ for the $i$-th network configuration, at which the FRP will occur.

For the set $\boldsymbol{D C N}$ we rank the configurations of electrical grid schemes in descending order of a frequency of FRP appearance. Thus, we determine the priority of the decision making to prevent a stable FRP for each scheme of electrical grid. This algorithm describes the procedure to determine the most dangerous configurations of electrical network schemes when the FRP will occur. In addition, it allows optimizing the choice of measures to prevent the damage of VT.

A specific measure to prevent the FRP in the grid (the replacement of VT with another type, the installation of a protection against FRP in the VT, the prevention of dangerous network configuration) should be chosen taking into account its cost, a possibility of technical realization and a technical policy of energy supply organisation regarding the operation of electromagnetic VT.

The antiresonant VT, that are installed at the new substations or are already operated in the electrical grids, must be equipped with protection devices against the influence of FRP. In the case with VT of NTMI, ZNOM types in electrical distribution grids of 6-35 kV, it is necessary to consider such options as an installation of protection systems against FRP on them or their replacement with antiresonant or non-resonant VT with a capacitive divider. In addition, the protection system of VT is many times cheaper than antiresonant and non-resonant VT.

It is advisable to do the replacement of VT of NTMI, ZNOM types by antiresonant VT of NAMI type in the electrical grids only if the capacitive network current in any network configuration does not fall in the range of an 
existence of the steady FRP. The antiresonant VT of NAMI type has a smaller range of capacitive earth fault currents at which the stable FRP can exist in the electrical grid.

\section{Conclusion}

1. According to the obtained results of the FRP investigation in the electrical distribution grids of $6-35 \mathrm{kV}$, the values of capacitive earth fault currents were determined at which the stable FRP occur in the electrical grid with the VT of NTMI, ZNOM, NAMI types.

2. A model for assessment the frequency of the stable FRP occurrence in the electrical grid was proposed based on the reliability analysis of physical objects during the external actions.

3. An algorithm for determining the most dangerous configurations of electrical grid schemes regarding the VT damage according to the frequency of stable FRP occurrence was developed. The selection of optimal measures to prevent the damage of VT was proposed.

\section{References}

[1] A. V. Zhurakhivskyi, Z. M. Bakhor, O. I. Hanus, P. P. Hovorov, A. Ya. Yatseiko, "Ferroresonance processes and protection of voltage transformers in the electrical grids of 6-35 kV: monograph", Lviv Polytechnic Publishing House, Lviv, 2019, 324 p. (in Ukrainian)

[2] A. V. Zhurakhivskyi, Yu. A. Kens, A. Ya. Yatseiko, R. Ya. Masliak, "Ferroresonance processes in $10 \mathrm{kV}$ power grids with different types of voltage transformers", Technical Electrodynamics, No. 2, 2010, pp. 73-77. (in Ukrainian)

[3] A. V. Zhurakhivskyi, A. Ya. Yatseiko, R. Ya. Masliak, "Operation modes of voltage transformers in the electrical grids with isolated neutral", Elektroinform, No. 1, 2009, pp. 8-11. (in Ukrainian)

[4] A. V. Zhurakhivskyi, Yu. A. Kens, A. Ya. Yatseiko, R. Ya. Masliak, "Protection of 6-35 kV electrical grids from ferroresonance processes", Technical Electrodynamics, No. 5, 2013, pp. 70-76. (in Ukrainian)

[5] Ju. L. Saenko, A. S. Popov, "Investigation of the causes of damage of voltage transformers for insulation monitoring", Power saving. Power engineering. Energy audit, Kharkiv, No. 7(89), 2011, pp. 59-66. (in Russian)

[6] A. V. Zhurakhivskyi, A. Ya. Yatseiko, R. Ya. Masliak, "Ferroresonance processes at the network frequency and ranges of attenuating resistors for its failure", Bulletin of the Lviv Polytechnic National University: Electric power and electromechanical systems, No. 834, 2015, pp. 20-25. (in Ukrainian)

[7] A. I. Ganus, K. A. Starkov, "Damageability of voltage transformers in regional electrical grids of AK "Kharkovoblenergo" and measures to reduce it", Light technics and electrical power engineering, Kharkiv, No. 1, 2003, pp. 76-81. (in Russian)

[8] A. I. Ganus, K. A. Starkov, "Influence of conditions of transient processes in electrical grids of 6-10 kV on the nature of damage of voltage transformers", Power engineering and electrification, No. 2, 2006, pp. 5-11. (in Russian)

[9] Z. Emin, B. Zahavi, D. Auckland, Y. Tong, "Ferroresonance in electromagnetic voltage transformers: a study based on nonlinear dynamics", IEEE Proc. on Generation, Transmission, Distribution, Vol. 144, 1997, pp. 383-387.

[10] "Rules of arrangement of electrical installations. Official publication. Ministry of Energy of Ukraine", Publishing House "Fort", Kharkiv, 2017, 760 p. (in Ukrainian)

[11] A. V. Zhurakhivskyi, Yu. A. Kens, R. V. Medynskyi, N. R. Zasidkovych, "Installation and testing of non-resonant voltage transformer of 610 kV", Power engineering and electrification, No. 8, 2001, pp. 17-22. (in Ukrainian)

[12] A. V. Zhurakhivskyi, B. M. Kinash, A. Ya. Yatseiko, R. Ya. Masliak, "Reliability analysis of the operation of voltage transformers in the conditions of ferroresonant actions", Technical Electrodynamics, No. 5, 2010, pp. 47-51. (in Ukrainian)

[13] T. Van Craenenbroeck (2003) Discussion of Modeling and Analysis Guidelines for Slow Transients. III. The Study of Ferroresonance. IEEE Transactions on Power Delivery, 18(4), 1592. doi: 10.1109/TPWRD.2003.810943.

[14] Arroyo, A., Martinez, R., Manana, M., Pigazo, A., Minguez, R. (2019) Detection of Ferroresonance Occurrence in Inductive Voltage Transformers through Vibration Analysis. International Journal of Electrical Power \& Energy Systems, 106, 294-300. https://doi.org/10.1016/j.ijepes.2018.10.011.

[15] Enrique, R., Pineda, P., Rodrigues, R., Aguila Tellez, A. (2018) Analysis and Simulation of Ferroresonance in Power Transformers using Simulink. IEEE Latin America Transactions, 16(2), 460-466. doi: 10.1109/TLA.2018.8327400.

[16] Abdelazim, T., Dionise, T. J., Yanniello, R. (2016) A Case Study of Voltage Transformer Failures in a Modern Data Center: Analysis, Mitigation, and Solution Implementation. IEEE/IAS 52nd Industrial and Commercial Power Systems Technical Conference (I\&CPS), 1-11. doi: 10.1109/ICPS.2016.7490257.

[17] Abdelazim, T., Dionise, T. J., Yanniello, R. (2016) Protecting Voltage Transformers from Switching Induced Transients and Ferroresonance. 2016 IEEE-IAS/PCA Cement Industry Technical Conference, Dallas, TX, 1-17. doi: 10.1109/CITCON.2016.7742671. 


\title{
Оцінка ферорезонансних процесів в схемах електричних мереж 6-35 кВ на основі аналізу надійності
}

\author{
Зіновій Бахор, Андрій Яцейко, Роман Ференсович
}

Національний університет «Львівська політехніка», вул. Степана Бандери, 12, Львів, 79013, Украйна

\begin{abstract}
Анотація
Об’єктом дослідження є вибір оптимального технічного рішення стосовно недопущення розвитку чи тривалого існування ферорезонансних процесів в розподільних електричних мережах 6-35 кВ, які працюють в режимі ізольованої нейтралі. На ймовірність виникнення та тривалість протікання ферорезонансних процесів впливає багато чинників: режим заземлення нейтралі мережі, їі ємнісний струм замикання на землю мережі, тип та кількість трансформаторів напруги тощо. За результатами дослідження визначено значення ємнісних струмів замикання на землю за яких у розподільчих електричних мережах 6-35 кВ виникають стійкі ферорезонансні процеси. Величини ємнісних струмів замикання на землю мережі є визначальними для виникнення стійкого ферорезонансу, але на характер його протікання також впливають додаткові випадкові фактори, такі як: напруга мережі, стан ізоляції ліній мережі, навантаження вторинної обмотки трансформатора напруги тощо. Тому було розроблено модель оцінювання частоти появи стійкого ферорезонансного процесу в мережі на основі аналізу надійності фізичних об’єктів в умовах зовнішніх діянь та алгоритм визначення найбільш небезпечних конфігурацій схем електричних мереж стосовно пошкодження трансформаторів напруги за частотою появи в них стійкого ферорезонансного процесу та вибір оптимальних заходів по недопущенню пошкодження трансформаторів напруги.
\end{abstract}

Ключові слова: електрична мережа; ферорезонанс; трансформатор напруги; ізольована нейтраль; аналіз надійності. 